\title{
Alicyclobacillus ferrooxydans sp. nov., a ferrous- oxidizing bacterium from solfataric soil
}

\author{
Cheng-Ying Jiang, Ying Liu, Yan-Yang Liu, Xiao-Yan You, Xu Guo \\ and Shuang-Jiang Liu
}

Correspondence
Shuang-Jiang Liu
liusj@sun.im.ac.cn

The genus Alicyclobacillus was first proposed to accommodate three Bacillus species that contained $\omega$-alicyclic fatty acids and were phylogenetically distant from other members of Bacillus (Wisotzkey et al., 1992). Subsequently, the genus was emended by Goto et al. (2003) to include species that did not contain $\omega$-alicyclic fatty acids, e.g. Alicyclobacillus pomorum (Goto et al., 2003). Currently, the genus Alicyclobacillus contains 18 species with validly published names, two subspecies and two genomic species (Fig. 1 and http://www.bacterio.cict.fr/a/alicyclobacillus.html). Most members of the genus Alicyclobacillus are thermoacidophilic, Gram-positive, spore-forming, heterotrophic organisms that often inhabit acidic geothermal environments such as geothermal water (Hiraishi et al., 1997; Nicolaus et al., 1998) and soil (Hippchen et al., 1981; Tsuruoka et al., 2003). Although the majority of Alicyclobacillus species mainly utilize organic compounds, Alicyclobacillus tolerans and Alicyclobacillus disulfidooxidans are able to oxidize ferrous iron, elemental sulfur and sulfides for growth (Kovalenko \& Malakhova, 1983; Dufresne et al., 1996). In this report, we describe a novel Alicyclobacillus strain, designated TC- $34^{\mathrm{T}}$, which grows by means of oxidation of ferrous iron, pyrite, tetrasulfate and thiosulfate.

The GenBank/EMBL/DDBJ accession number for the $16 \mathrm{~S}$ rRNA gene sequence of strain $\mathrm{TC}-34^{\top}$ is EU137838.

A table detailing the cellular fatty acid compositions of the type/ reference strains of Alicyclobacillus ferrooxydans sp. nov. and related Alicyclobacillus species is available as supplementary material with the online version of this paper.
Strain TC- $34^{\mathrm{T}}$ was isolated from solfataric samples (temperature and $\mathrm{pH}$ ranges of $48-50{ }^{\circ} \mathrm{C}$ and $4.5-5.5$, respectively) from Tengchong county $\left(24^{\circ} 38^{\prime}-25^{\circ} 52^{\prime} \mathrm{N} 98^{\circ} 05^{\prime}-\right.$ $98^{\circ} 46^{\prime}$ E), Yunnan Province, China, using modified Norris broth that contained a mineral salts medium (Norris et al., 1996) supplemented with $14.0 \mathrm{~g} \mathrm{FeSO}_{4} \cdot 7 \mathrm{H}_{2} \mathrm{O} \mathrm{l}^{-1}$ and $0.2 \mathrm{~g}$ yeast extract $1^{-1}$. For the preparation of modified Norris solid medium, $14.0 \mathrm{~g}$ Gelrite Gellan Gum $1^{-1}$ (Sigma) was added to the modified broth. The samples collected were first enriched at $30{ }^{\circ} \mathrm{C}$ using modified broth. After three enrichments, the enriched culture was serially diluted (10-fold) in tubes containing $0.9 \mathrm{ml}$ modified Norris broth. Aliquots $(0.2 \mathrm{ml})$ of the diluted cultures were spread on plates to obtain individual colonies. Further purification of a single colony was carried out by repeated streaking on plates of modified Norris medium. The purity of strain TC- $34^{\mathrm{T}}$ was checked by means of $16 \mathrm{~S}$ rRNA gene sequence analysis and the phenotypic homogeneity of the culture.

Cell morphology and flagellation were examined by using transmission electron microscopy of cells in the exponential growth phase in modified Norris broth. Physiological and chemotaxonomical characterization of strain $\mathrm{TC}-34^{\mathrm{T}}$ was carried out using BAM medium (Deinhard et al., 1987a), modified by the addition of $2.0 \mathrm{~g}$ soluble starch $1^{-1}$ and a reduction in the concentrations of yeast extract and glucose to final values of 0.2 and $0.5 \mathrm{~g} \mathrm{l}^{-1}$, respectively. Gram-reactions were determined according to the method described by Gerhardt et al. (1994). Endospore formation was observed after malachite green staining of cells from a 


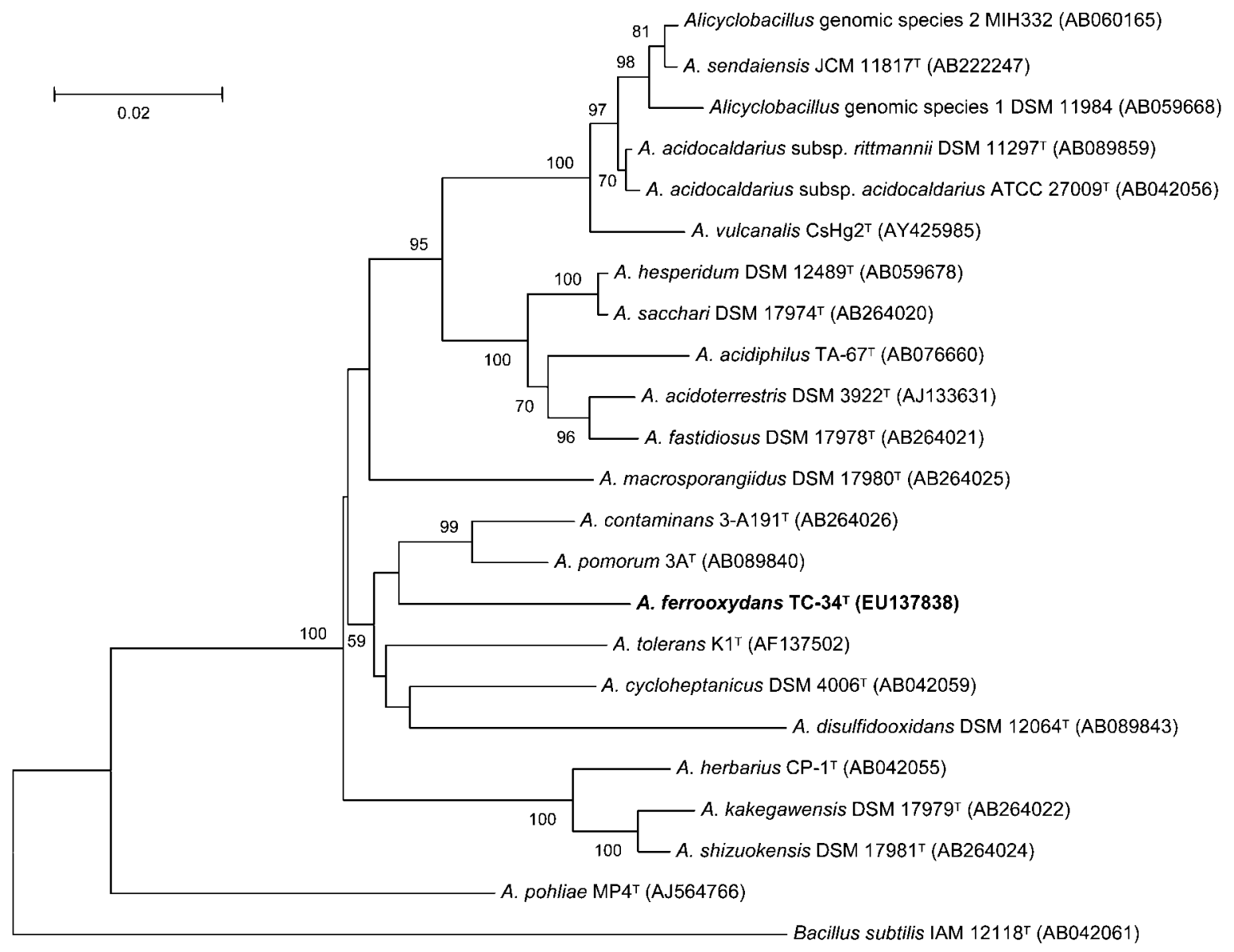

Fig. 1. Phylogenetic tree constructed using the neighbour-joining method according to $16 \mathrm{~S}$ rRNA gene sequence evolutionary distances among strain TC-34 $4^{\top}$ and other Alicyclobacillus species. Bacillus subtilis IAM $12118^{\top}$ was used as the outgroup. GenBank accession numbers are given in parentheses. Numbers at nodes are bootstrap percentages (only values greater than $50 \%$ are shown) based on 1000 replicates. Bar, evolutionary distance $\left(K_{\text {nuc }}\right)$ of 0.02 substitutions per nucleotide position.

6 day-old culture in modified BAM broth. Unless otherwise stated, catalase and oxidase activities, the VogesProskauer reaction, carbon source utilization and other biochemical characterization tests were performed as described by Deinhard et al. (1987a, b), Albuquerque et al. (2000) and Goto et al. (2002) using modified BAM media. The strains were characterized biochemically using the API ZYM, API 20NE and API $50 \mathrm{CH}$ systems (bioMérieux), with modified BAM basal salts medium. Cell concentrates were resuspended in $15 \mathrm{ml}$ modified BAM medium, at $\mathrm{pH} 4.0$ and with $0.03 \mathrm{~g}$ bromophenol blue $\mathrm{l}^{-1}$ as indicator, and distributed in the API $50 \mathrm{CH}$ test strip wells. The results for acid production were read after incubation at $30{ }^{\circ} \mathrm{C}$ for $48-96 \mathrm{~h}$, according to the manufacturer's instructions. The temperature range for growth was examined with a $\mathrm{TN} 3 \mathrm{~F}$ temperature-gradient incubator (Advantec) and modified Norris broth. The $\mathrm{pH}$ range of 0.5-7.0 (in increments of $0.5 \mathrm{pH}$ units, adjusted by the addition of $1 \mathrm{M}$ $\mathrm{H}_{2} \mathrm{SO}_{4}$ ) for growth was examined using modified BAM medium. Cell growth was determined by measuring the increase in optical density at $460 \mathrm{~nm}\left(\mathrm{OD}_{460}\right)$.
For analysis of the cellular fatty acids, strain $\mathrm{TC}-34^{\mathrm{T}}$ was grown for 5 days at $30{ }^{\circ} \mathrm{C}$ on modified BAM agar. Cells were harvested from the plates, and the fatty acids were methylated and analysed by using the Sherlock Microbial Identification System according to the manufacturer's instructions (Microbial ID). Isoprenoid quinones were extracted from freeze-dried cells $(200 \mathrm{mg})$ with chloroform/methanol $(2: 1, \mathrm{v} / \mathrm{v})$, and then separated from other components by using thin-layer chromatography. Purified isoprenoid quinones were analysed by reversed-phase HPLC with a ZOBAX ODS $\mathrm{C}_{18}$ column (Agilent Co.), with acetonitrile/isopropyl alcohol $(2: 1.2, \mathrm{v} / \mathrm{v})$ as the mobile phase. The DNA base composition was determined by using the thermal denaturation method (Marmur \& Doty, 1962) with DNA from Escherichia coli K-12 as a reference.

A nearly complete $16 \mathrm{~S}$ rRNA gene of strain TC- $34^{\mathrm{T}}$ was amplified with the primers $27 \mathrm{f}\left(5^{\prime}\right.$-AGAGTTTGATCTTGGCTCAG- $\left.3^{\prime}\right)$ and 1492r (5'-TACGGCTACCTTGTTACGACTT- $\left.3^{\prime}\right)$ and sequenced. Alignments of 16S rRNA gene 
sequences were performed using the program CLUSTAL_X, version 1.64b (Thompson et al., 1994), and positions with insertions or deletions were excluded during calculations. A neighbour-joining phylogenetic tree was constructed using MEGA 3.1 (Saitou \& Nei, 1987; Kumar et al., 2004), based on evolutionary distances that were calculated with the Kimura two-parameter model (Kimura, 1980).

Cells of strain $\mathrm{TC}-34^{\mathrm{T}}$ were Gram-positive, aerobic, endospore-forming, coccoids or rods. Flagella were not observed. Catalase and oxidase were positive. Colonies of strain $\mathrm{TC}-34^{\mathrm{T}}$ on plates of modified Norris medium were brown at the centre and yellow-orange in the periphery. The colonies were circular and flat, with entire margins, with diameters of $0.3-0.5 \mathrm{~mm}$ after incubation for 56 days. Carbon compounds that supported growth and acid production are given in the species description.

Strain TC- $34^{\mathrm{T}}$ grew at $17-40{ }^{\circ} \mathrm{C}$ and $\mathrm{pH} 2.0-6.0$, and optimally at $28{ }^{\circ} \mathrm{C}$ and $\mathrm{pH} 3.0$. The following compounds were tested as energy sources: $5.0 \mathrm{~g}$ elemental sulfur $1^{-1}$, $10 \mathrm{mmol} \mathrm{K}_{2} \mathrm{~S}_{4} \mathrm{O}_{6} \mathrm{l}^{-1}, 5 \mathrm{mmol} \mathrm{Na}_{2} \mathrm{~S}_{2} \mathrm{O}_{3} \mathrm{l}^{-1}$ and $5.0 \mathrm{~g} \mathrm{FeS}_{2}$ $1^{-1}$. Strain TC- $34^{\mathrm{T}}$ oxidized ferrous iron, $\mathrm{K}_{2} \mathrm{~S}_{4} \mathrm{O}_{6}$ and pyrite as electron donors for growth, but not elemental sulfur. Fig. 2 clearly shows that the biomass production of strain $\mathrm{TC}-34^{\mathrm{T}}$ was proportional to the oxidation of $\mathrm{Fe}^{2+}$. The graph in Fig. 2 also shows that oxidation of ferrous iron by strain $\mathrm{TC}-34^{\mathrm{T}}$ was affected by temperature. Maximum oxidation of ferrous iron occurred at $28-30{ }^{\circ} \mathrm{C}$, the same range as that for the optimal growth temperature. Oxidation of ferrous iron by other Alicyclobacillus species such as A. tolerans, A. disulfidooxidans (Karavaiko et al., 2005) and A. pohliae (Imperio et al., 2008) has been reported previously. This property of members of the genus Alicyclobacillus is considered to be related to habitat and is ecologically important.

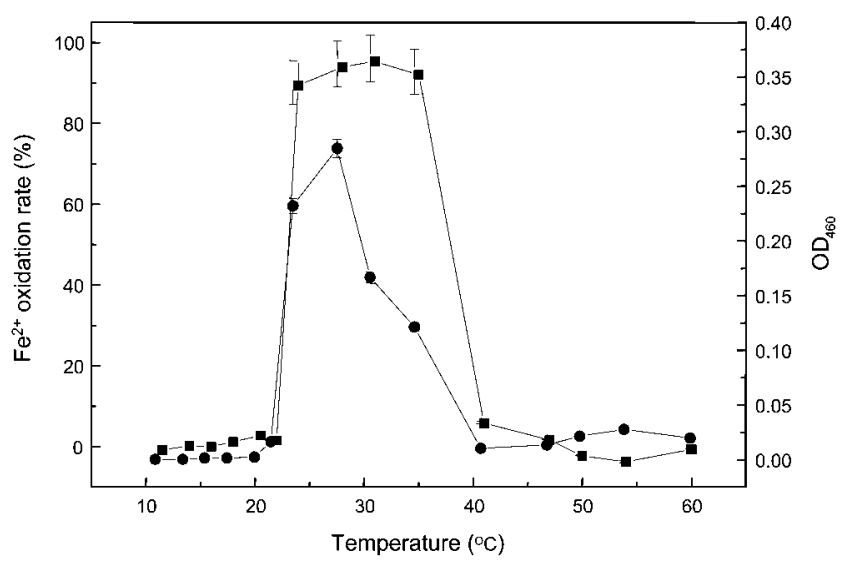

Fig. 2. Growth of and $\mathrm{Fe}^{2+}$ oxidation by strain $\mathrm{TC}-34^{\top}$ at different temperatures. Data shown are means of three parallel experiments. Error bars indicate SD. $\mathbf{\square}, \mathrm{Fe}^{2+}$ oxidation rate; $\bullet, \mathrm{OD}_{460}$. The experiments were conducted using modified Norris medium (Norris et al., 1996).
The predominant cellular fatty acids of strain $\mathrm{TC}-34^{\mathrm{T}}$ were anteiso- $\mathrm{C}_{15: 0}(37.2 \%)$, anteiso- $\mathrm{C}_{17: 0}(25.3 \%)$, iso- $\mathrm{C}_{16: 0}$ $(22.2 \%)$ and iso- $\mathrm{C}_{15: 0}(9.8 \%) . \omega$-Alicyclic fatty acids were not detected. This property was similar to A. pomorum (Goto et al., 2003), but was different from the majority of Alicyclobacillus species. Detailed information on the cellular fatty acid composition is provided in the species description and a comparison of the fatty acid profiles of various Alicyclobacillus species is provided in Supplementary Table S1 (available in IJSEM Online). The major respiratory quinone of strain $\mathrm{TC}-34^{\mathrm{T}}$ was menaquinone 7 (MK-7). A trace amount of MK-6 was also detected. The G+C content of the DNA of strain TC- $34^{\mathrm{T}}$ was $48.6 \mathrm{~mol} \%$, which was close to the range for other Alicyclobacillus species (48.7-62.7 mol\%) (Karavaiko et al., 2005).

The 16S rRNA gene sequence analysis showed that strain TC- $34^{\mathrm{T}}$ was phylogenetically related to members of the genus Alicyclobacillus (90.8-94.8\% similarity), with the highest similarity (94.8\%) with A. pomorum. The neighbour-joining tree (Fig. 1) showed that strain TC- $34^{\mathrm{T}}$ clustered with Alicyclobacillus species.

Based on the above phenotypic and phylogenetic studies, it is clear that strain TC- $34^{\mathrm{T}}$ represents a novel species of the genus Alicyclobacillus. Strain TC- $34^{\mathrm{T}}$ showed a range of phenotypic characteristics that were different from those of recognized Alicyclobacillus species (Table 1). The most distinctive features were that strain $\mathrm{TC}-34^{\mathrm{T}}$ is mesotrophic, oxidizes ferrous iron and does not contain $\omega$-alicyclic fatty acids. Other differences include the ability to assimilate various carbon sources and to oxidize inorganic ferrous iron or sulfuric compounds. The major cellular fatty acids are also significantly different from those of other Alicyclobacillus species.

Based on the results presented here, it is concluded that strain TC- $34^{\mathrm{T}}$ represents a novel species of the genus Alicyclobacillus, for which the name Alicyclobacillus ferrooxydans sp. nov. is proposed.

\section{Description of Alicyclobacillus ferrooxydans sp. nov.}

Alicyclobacillus ferrooxydans (fer.ro.ox'y.dans. L. n. ferrum iron; Gr. adj. oxys sharp, acid; N.L. v. oxydare to make acid, to oxidize; N.L. part. adj. ferrooxydans iron-oxidizing).

Cells are Gram-positive, strictly aerobic, non-motile, endospore-forming coccoids or rods with rounded ends $(0.4-0.6 \times 1.0-1.5 \mu \mathrm{m})$. Colonies on plates of modified Norris broth are brown in the centre, with the peripheries being yellow-orange, with diameters of $0.3-0.5 \mathrm{~mm}$. Colonies on modified BAM agar are non-pigmented, pinpoint and circular, with entire margins, with diameters of $0.3-0.5 \mathrm{~mm}$. Growth is stimulated by yeast extract. Growth occurs in the presence of $0-3 \% \mathrm{NaCl}$, but not in $4 \% \mathrm{NaCl}$. Oxidase, catalase and indole production are positive, but nitrate reduction, methyl red and VogesProskauer tests are negative. Hydrogen sulfide $\left(\mathrm{H}_{2} \mathrm{~S}\right)$ is not 
Table 1. Phenotypic characteristics that differentiate strain TC-34 ${ }^{\top}$ from other Alicyclobacillus species

Strains: 1, strain TC-34 ${ }^{\mathrm{T}}$ (A. ferrooxydans sp. nov.); 2, A. pomorum $3 \mathrm{~A}^{\mathrm{T}} ; 3$, A. contaminans $3-\mathrm{A}_{191}{ }^{\mathrm{T}} ; 4$, A. tolerans $\mathrm{K}^{\mathrm{T}}$ (Karavaiko et al., 2005); 5, A. hesperidum DSM 12489 ${ }^{\mathrm{T}}$; 6, A. macrosporangiidus DSM $17980^{\mathrm{T}} ; 7$, A. acidoterrestris DSM $3922^{\mathrm{T}} ; 8$, A. sacchari DSM $17974^{\mathrm{T}} ; 9$, A. cycloheptanicus DSM 4006 ${ }^{\mathrm{T}} ; 10$, A. acidiphilus TA $-67^{\mathrm{T}}$; 11 , A. fastidiosus DSM 17978 ${ }^{\mathrm{T}}$; 12 , A. kakegawensis DSM

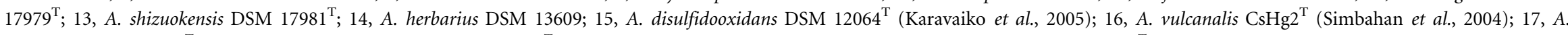
sendaiensis JCM $11817^{\mathrm{T}}$ (Tsuruoka et al., 2003); 18, A. pohliae MP4 ${ }^{\mathrm{T}}$ (Imperio et al., 2008); 19, A. acidocaldarius subsp. acidocaldarius 101-1A ${ }^{\mathrm{T}}$. If not indicated otherwise, data are from this study. For all tests, A. hesperidum DSM $12489^{\mathrm{T}}$ was run in parallel with strain TC-34 ${ }^{\mathrm{T}}$. When the results for $A$. hesperidum DSM $12489^{\mathrm{T}}$ from this study were different from those reported by Albuquerque et al. (2000) and Goto et al. (2007), the results from this study are given and the previous results are given in parentheses. +, Positive; -, negative; ND, not determined; W, weakly positive; V, variable.

\begin{tabular}{|c|c|c|c|c|c|c|c|c|c|c|c|c|c|c|c|c|c|c|c|}
\hline Characteristic & 1 & 2 & 3 & 4 & 5 & 6 & 7 & 8 & 9 & 10 & 11 & 12 & 13 & 14 & 15 & 16 & 17 & 18 & 19 \\
\hline $\begin{array}{l}\text { Temperature range for growth } \\
\left({ }^{\circ} \mathrm{C}\right)\end{array}$ & $\begin{array}{c}17- \\
40\end{array}$ & $\begin{array}{c}30- \\
60\end{array}$ & $\begin{array}{c}35- \\
60\end{array}$ & $\begin{array}{c}20- \\
55\end{array}$ & $\begin{array}{c}35- \\
60\end{array}$ & $\begin{array}{c}35- \\
60\end{array}$ & $\begin{array}{c}35- \\
55\end{array}$ & $\begin{array}{c}30- \\
55\end{array}$ & $\begin{array}{c}40- \\
53\end{array}$ & $\begin{array}{c}20- \\
50\end{array}$ & $\begin{array}{c}20- \\
55\end{array}$ & $\begin{array}{c}40- \\
60\end{array}$ & $\begin{array}{c}35- \\
60\end{array}$ & $\begin{array}{c}35- \\
65\end{array}$ & $\begin{array}{l}4- \\
40\end{array}$ & $\begin{array}{c}35- \\
65\end{array}$ & $\begin{array}{c}40- \\
65\end{array}$ & $\begin{array}{c}42- \\
60\end{array}$ & $\begin{array}{c}45- \\
70\end{array}$ \\
\hline $\mathrm{pH}$ range for growth & $\begin{array}{c}2.0- \\
6.0\end{array}$ & $\begin{array}{c}3.0- \\
6.0\end{array}$ & $\begin{array}{c}3.0- \\
6.0\end{array}$ & $\begin{array}{l}1.5- \\
5.0\end{array}$ & $\begin{array}{c}2.0- \\
6.0\end{array}$ & $\begin{array}{c}3.0- \\
6.5\end{array}$ & $\begin{array}{c}2.2- \\
5.8\end{array}$ & $\begin{array}{c}2.0- \\
6.5\end{array}$ & $\begin{array}{c}3.0- \\
5.5\end{array}$ & $\begin{array}{l}2.5- \\
5.5\end{array}$ & $\begin{array}{c}2.0- \\
5.5\end{array}$ & $\begin{array}{c}3.0- \\
6.5\end{array}$ & $\begin{array}{c}3.0- \\
6.5\end{array}$ & $\begin{array}{c}3.0- \\
6.5\end{array}$ & $\begin{array}{c}0.5- \\
6.0\end{array}$ & $\begin{array}{c}2.0- \\
6.0\end{array}$ & $\begin{array}{c}2.5- \\
6.5\end{array}$ & $\begin{array}{l}4.5- \\
7.5\end{array}$ & $\begin{array}{c}2.0- \\
6.0\end{array}$ \\
\hline DNA G $+C$ content $(\mathrm{mol} \%)$ & 48.6 & 53.1 & 60.3 & $\begin{array}{c}48.7 \pm \\
0.6\end{array}$ & 53.3 & 62.5 & 52.2 & 56.6 & 55.6 & 54.1 & 53.9 & $\begin{array}{c}61.5 \pm \\
0.2\end{array}$ & 60.5 & 56.2 & 53.0 & 62.0 & 62.3 & 55.1 & 60.3 \\
\hline Oxidase & + & + & - & $\mathrm{w}$ & - & - & - & - & + & - & - & - & - & - & - & ND & - & - & - \\
\hline Catalase & + & + & - & $\mathrm{w}$ & $-(+)$ & $\mathrm{w}$ & + & - & + & + & + & $\mathrm{w}$ & + & + & - & - & - & - & + \\
\hline Hydrolysis of: & & & & & & & & & & & & & & & & & & & \\
\hline Gelatin & - & + & + & - & + & - & + & + & - & - & + & - & - & - & - & ND & ND & $\mathrm{ND}$ & + \\
\hline Starch & + & + & - & + & + & - & - & + & - & - & - & - & - & - & + & + & ND & ND & + \\
\hline Nitrate reduced to nitrite & - & - & - & - & - & - & - & - & - & - & - & - & - & + & - & ND & + & ND & - \\
\hline Growth at $5 \% \mathrm{NaCl}$ & - & - & - & $\mathrm{ND}$ & - & + & + & - & + & - & - & - & + & + & ND & - & $\mathrm{ND}$ & - & - \\
\hline $\begin{array}{l}\text { Acid production from: } \\
\text { Glvcerol }\end{array}$ & - & + & + & $\mathrm{w}$ & + & + & + & + & - & - & - & - & - & + & + & ND & + & - & + \\
\hline D-Arabinose & - & - & - & w & - & + & - & - & + & + & + & + & - & + & + & ND & + & + & - \\
\hline L-Arabinose & + & - & + & w & + & + & + & + & + & + & + & + & + & + & + & ND & + & + & + \\
\hline D-Xylose & - & - & + & + & $+(-)$ & + & - & + & + & + & + & + & + & + & + & $\mathrm{ND}$ & $\mathrm{ND}$ & + & + \\
\hline L-Xylose & - & - & - & + & - & + & - & - & + & - & - & + & + & - & + & ND & $\mathrm{ND}$ & + & - \\
\hline Methyl $\beta$-D-xyloside & + & - & - & + & - & - & - & + & - & - & + & - & - & - & ND & - & ND & - & - \\
\hline D-Galactose & - & - & + & + & + & + & + & + & - & + & + & + & + & + & - & $\mathrm{ND}$ & + & + & + \\
\hline L-Sorbose & - & + & $\mathrm{v}$ & + & - & + & - & - & + & + & - & + & - & - & + & ND & $\mathrm{ND}$ & + & - \\
\hline L-Rhamnose & - & - & $\mathrm{v}$ & - & - & + & + & + & + & - & + & + & - & + & - & - & - & + & + \\
\hline D-Mannitol & - & + & + & + & + & - & + & + & + & - & + & + & + & + & + & + & $\mathrm{ND}$ & - & + \\
\hline D-Sorbitol & + & - & - & - & - & + & + & - & + & + & - & + & - & - & - & - & - & - & - \\
\hline Methyl $\alpha$-D-mannoside & + & - & - & + & - & + & - & - & - & - & - & + & - & + & ND & ND & ND & - & - \\
\hline Amygdalin & - & + & - & + & - & - & - & - & - & - & - & + & - & + & + & $\mathrm{ND}$ & - & - & - \\
\hline Arbutin & - & - & + & - & $+(-)$ & - & - & + & - & + & - & + & + & + & - & w & + & $\mathrm{w}$ & + \\
\hline Aesculin & + & + & + & + & $+(-)$ & + & - & - & + & + & - & + & + & + & + & ND & - & + & + \\
\hline Salicin & - & + & $\mathrm{v}$ & - & - & + & - & + & - & + & - & + & + & + & - & - & + & $\mathrm{w}$ & + \\
\hline Cellobiose & - & - & + & - & + & - & + & + & - & + & - & + & + & + & + & ND & + & + & + \\
\hline Maltose & - & + & + & $\mathrm{w}$ & + & + & + & + & - & + & - & + & + & + & + & ND & + & + & + \\
\hline
\end{tabular}




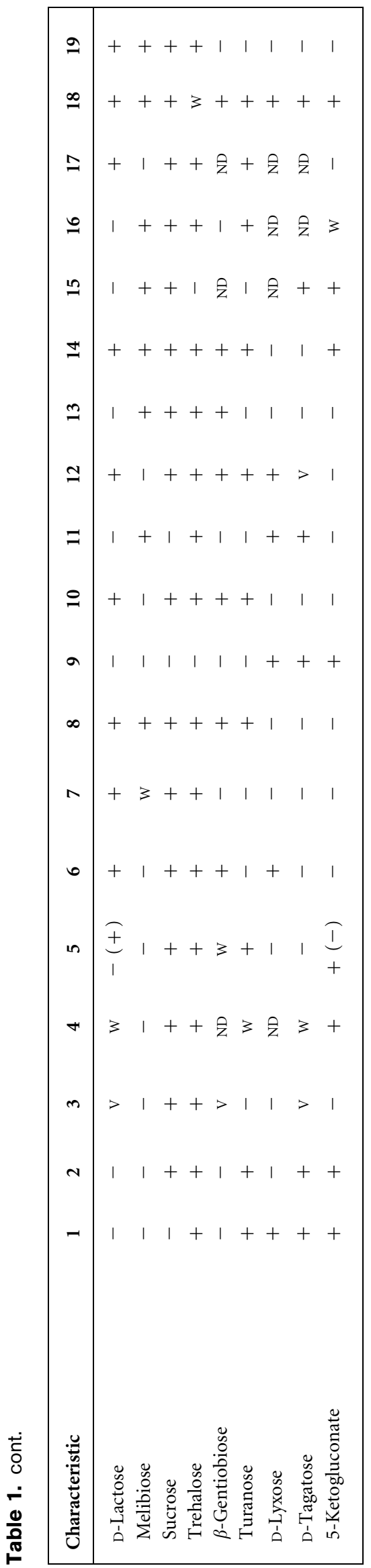

produced. Starch and casein are hydrolysed, but gelatin, Tween 80, aesculin and DNase are not. Phosphatase, esterase and lipase activities are positive. L-Lysine decarboxylases, L-ornithine decarboxylases and L-phenylalanine deaminase are absent. Utilizes the following carbon sources: L-arabinose, cellobiose, erythritol, L-fucose, Dmannose, maltose, D-fructose, D-sorbitol, D-galactose and D-glucose, but not glycerol, aesculin, melezitose, D-mannitol, raffinose, inositol, D-lactose, L-phenylalanine, Lcysteine, peptone or xylitol. Acid is produced from L-arabinose, methyl $\beta$-D-xyloside, methyl $\alpha$-D-mannoside, trehalose, sorbitol, D-glucose, turanose, D-lyxose, D-tagatose, 5-ketogluconate and aesculin, but not from glycerol, erythritol, D-arabinose, D-xylose, L-xylose, D-galactose, L-sorbose, L-rhamnose, inositol, D-mannitol, methyl $\alpha$-Dglucopyranoside, amygdalin, arbutin, salicin, cellobiose, maltose, D-lactose, melibiose, sucrose, inulin, melezitose, raffinose, glycogen, xylitol, $\beta$-gentiobiose, D-fucose, Lfucose or D-arabitol. Uses $\mathrm{Fe}^{2+}, \mathrm{K}_{2} \mathrm{~S}_{4} \mathrm{O}_{6}$ and pyrite for energy. Cellular fatty acids are anteiso- $\mathrm{C}_{15: 0}$, anteiso- $\mathrm{C}_{17: 0 \text {, }}$ iso- $\mathrm{C}_{16: 0}$ and iso- $\mathrm{C}_{15: 0}$. Major isoprenoid quinone is menaquinone 7 (MK-7). The DNA G $+\mathrm{C}$ content of the type strain is $48.6 \mathrm{~mol} \%$.

The type strain, TC- $34^{\mathrm{T}}\left(=\mathrm{JCM} 15090^{\mathrm{T}}=\mathrm{CGMCC} 1.6357^{\mathrm{T}}\right)$, was isolated from solfataric soil of Tengchong county of Yunnan province, China.

\section{Acknowledgements}

This work was supported by grants (30670018 and 30621005) of National Nature Science Foundation of China.

\section{References}

Albuquerque, L., Rainey, F. A., Chung, A. P., Sunna, A., Nobre, M. F., Grote, R., Antranikian, G. \& De Costa, M. S. (2000). Alicyclobacillus hesperidum sp. nov. and a related genomic species from solfataric soils of São Miguel in the Azores. Int J Syst Evol Microbiol 50, 451-457.

Deinhard, G., Blanz, P., Poralla, K. \& Alton, E. (1987a). Bacillus acidoterrestris sp. nov., a new thermotolerant acidophile isolated from different soils. Syst Appl Microbiol 10, 47-53.

Deinhard, G., Saar, J., Krischke, W. \& Poralla, K. (1987b). Bacillus cycloheptanicus sp. nov., a new thermoacidophile containing $\omega$ cycloheptane fatty acids. Syst Appl Microbiol 10, 68-73.

Dufresne, S., Bousquet, J., Boissinot, M. \& Guay, R. (1996). Sulfobacillus disulfidooxidans sp. nov., a new acidophilic, disulfide oxidizing, Grampositive, spore-forming bacterium. Int J Syst Bacteriol 46, 1056-1064.

Gerhardt, P., Murray, R. G. E., Wood, W. A. \& Krieg, N. R. (1994). Methods for General and Molecular Bacteriology. Washington, DC: American Society for Microbiology.

Goto, K., Mochida, K., Asahara, M., Suzuki, M. \& Yokota, A. (2002). Application of the hypervariable region of the $16 \mathrm{~S}$ rDNA sequence as an index for the rapid identification of species in the genus Alicyclobacillus. J Gen Appl Microbiol 48, 243-250.

Goto, K., Mochida, K., Asahara, M., Suzuki, M., Kasai, H. \& Yokota, K. (2003). Alicyclobacillus pomorum sp. nov., a novel thermoacidophilic, endospore-forming bacterium that does not possess $\omega$-alicyclic fatty acids, and emended description of the genus Alicyclobacillus. Int J Syst Evol Microbiol 53, 1537-1544. 
Goto, K., Mochida, K., Kato, Y., Asahara, M., Fujita, R., An, S.-Y., Kasai, H. \& Yokota, A. (2007). Proposal of six species of moderately thermophilic, acidophilic, endospore-forming bacteria: Alicyclobacillus contaminans sp. nov., Alicyclobacillus fastidiosus sp. nov., Alicyclobacillus kakegawensis sp. nov., Alicyclobacillus macrosporangiidus sp. nov., Alicyclobacillus sacchari sp. nov. and Alicyclobacillus shizuokensis sp. nov. Int J Syst Evol Microbiol 57, 1276-1285.

Hippchen, B., Roll, A. \& Poralla, K. (1981). Occurrence in soil of thermo-acidophilic bacilli possessing $\omega$-cyclohexane fatty acids and hopanoids. Arch Microbiol 129, 53-55.

Hiraishi, A., Inagaki, K., Tanimoto, Y., Iwasaki, M., Kishimoto, N. \& Tanaka, H. (1997). Phylogenetic characterization of a new thermoacidophilic bacterium isolated from hot spring in Japan. J Gen Appl Microbiol 43, 295-304.

Imperio, T., Viti, C. \& Marri, L. (2008). Alicyclobacillus pohliae sp. nov., a thermophilic, endospore-forming bacterium isolated from geothermal soil of the north-west slope of Mount Melbourne (Antarctica). Int J Syst Evol Microbiol 58, 221-225.

Karavaiko, G. I., Bogdanova, T. I., Tourova, T. P., Kondrat'eva, T. F., Tsaplina, I. A., Egorova, M. A., Krasil'nikova, E. N. \& Zakharchuk, L. M. (2005). Reclassification of 'Sulfobacillus thermosulfidooxidans subsp. thermotolerans' strain K1 as Alicyclobacillus tolerans sp. nov. and Sulfobacillus disulfidooxidans Dufresne et al. 1996 as Alicyclobacillus disulfidooxidans comb. nov., and emended description of the genus Alicyclobacillus. Int J Syst Evol Microbiol 55, 941-947.

Kimura, M. (1980). A simple method for estimating evolutionary rates of base substitutions through comparative studies of nucleotide sequence. J Mol Evol 16, 111-120.

Kovalenko, E. V. \& Malakhova, P. T. (1983). The spore-forming ironoxidizing bacterium Sulfobacillus thermosulfidooxidans. Microbiology (English translation of Mikrobiologiia) 52, 962-966.
Kumar, S., Tamura, K. \& Nei, M. (2004). MEGA3: integrated software for Molecular Evolutionary Genetics Analysis and sequence alignment. Brief Bioinform 5, 150-163.

Marmur, J. \& Doty, P. (1962). Determination of the base composition of deoxyribonucleic acid from its thermal denaturation temperature. $J$ Mol Biol 5, 109-118.

Nicolaus, B., Improta, R., Manca, M. C., Lama, L., Esposito, E. \& Gambacorta, A. (1998). Alicyclobacilli from an unexplored geothermal soil in Antarctica: Mount Rittmann. Polar Biol 19, 133-141.

Norris, P. R., Clark, D. A. \& Owen, J. P. (1996). Characteristics of Sulfobacillus acidophilus sp. nov. and other moderately thermophilic mineral-sulphide-oxidizing bacteria. Microbiology 142, 775-783.

Saitou, N. \& Nei, M. (1987). The neighbor-joining method: a new method for reconstructing phylogenetic trees. Mol Biol Evol 4, 406-425.

Simbahan, J., Drijber, R. \& Blum, P. (2004). Alicyclobacillus vulcanalis sp. nov., a thermophilic, acidophilic bacterium isolated from Coso Hot Spring, California, USA. Int J Syst Evol Microbiol 54, 1703-1707.

Thompson, J. D., Higgins, D. G. \& Gibson, T. J. (1994). Clustal W: improving the sensitivity of progressive multiple sequence alignment through sequence weighting, position-specific gap penalties and weight matrix choice. Nucleic Acids Res 22, 4673-4680.

Tsuruoka, N., Isono, Y., Shida, O., Hemmi, H., Nakayama, T. \& Nishio, T. (2003). Alicyclobacillus sendaiensis sp. nov., a novel acidophilic, slightly thermophilic species isolated from soil in Sendai, Japan. Int J Syst Evol Microbiol 53, 1081-1084.

Wisotzkey, J. D., Jurtshuk, P. Jr, Fox, G. E., Deinhard, G. \& Poralla, K. (1992). Comparative sequence analyses on the $16 \mathrm{~S}$ rRNA (rDNA) of Bacillus acidocaldarius, Bacillus acidoterrestris, and Bacillus cycloheptanicus and proposal for creation of a new genus, Alicyclobacillus gen. nov. Int J Syst Bacteriol 42, 263-269. 